\title{
KYAI POLICY IMPLEMENTATION IN IMPROVING TEACHER PERFORMANCE IN DARUL MUTTAQIEN BOGOR PONDOK
}

\author{
Nunung Kurniasih \\ Universitas Islam Nusantara, Bandung, Indonesia \\ Email: nunung.s327@gmail.com \\ R. Supyan Sauri \\ Universitas Islam Nusantara, Bandung, Indonesia \\ Email: uyunsufyan@yahoo.co.id \\ Ujang Cepi Barlian \\ Universitas Islam Nusantara, Bandung, Indonesia \\ Email: ujangcepibarlian@yahoo.co.id
}

\begin{abstract}
The purpose of this study was to describe the implementation of kyai policies in improving teacher performance in Islamic boarding schools. The method used is a descriptive method as a problem-solving procedure which is investigated by describing or describing the condition of the subject or object of research (a person, institution, society, etc.) at the present time based on visible facts, or as it should be. The results of the study illustrate that the kyai's policy in improving teacher performance at the Darul Muttaqien Parung Islamic Boarding School, Bogor is based on Panca Jiwa, which means Panca means five, soul means spirit, Pondok means boarding school institution, which substantively contains positive values that do not conflict with the teachings. Islamic teachings. The five spirits of the pesantren, namely; Sincerity, Simplicity, Independence, Ukhuwwah Islamiyyah and Freedom.
\end{abstract}

Keywords: Implementation, Education Policy, Teacher Performance

\section{A. INTRODUCTION}

Learning is one aspect that plays an important role in the education management process, because no matter how good written learning tools are, if they are not implemented efficiently and effectively, the learning outcomes achieved in terms of knowledge, attitudes and skills will be inadequate. Therefore, the quality of an education can be seen from the quality of the learning process. For this reason, the criteria for the quality and success of learning must be made in detail so that they can be measured and observed (Sarifudin, 2019).

Teachers are at the forefront of dealing directly with students through learning activities in class or outside the classroom. It is clear that teachers are also required to carry out all their professional functions effectively and efficiently, both from the interests of national education and the functional duties of teachers. Everything demands that education and teaching be carried out professionally, meaning that it is carried out seriously and is supported by teachers who have good performance (Hafid, 2017).

The term performance is a translation from English "performance" which means work performance, work implementation, work results and work performance. Meanwhile, according to Snell, what is meant by performance is the culmination of three interrelated elements, namely 
skills, efforts and external characteristics. The skill level is the raw material that a person brings to the place where he works. Such as knowledge, abilities, interpersonal skills and technical skills. The level of effort is described as the motivation shown by a person to complete his job. While the external nature is the degree to which external conditions can support one's performance (Harjali, 2016).

The professionalism of a teacher based on Law no. 14 of 2005 on Teachers and Lecturers includes four main things, namely: a) pedagogic competency; b) personality competency; c) professional competence (professionalism competency); and d) social competency. Of the four teacher competencies above, competencies that are directly related to the academic field are shown by pedagogic and professional competencies. Pedagogical competence relates to the basic technical skills of teachers in managing learning, while professional competence is the ability of each teacher in terms of mastering the substance of learning materials according to their expertise. Teachers who have mastery of pedagogic competence and professional competence are reflected in the learning process at the educational institution where they work (Wathani, 2020).

Houle stated that the characteristics of a professional job are: First. Must have a strong knowledge base. Second. Based on individual competence, not on the basis of KKN (Corruption, Collusion and Nepotism). Third. Has a selection and certification system. Fourth. There is healthy cooperation and competition between peers. Fifth. There is high professional awareness. Sixth. Have ethical principles. Seventh. Have a professional sanction system. Eighth. The existence of individual militancy. Ninth. Has a professional organization (Meria, 2016). When Hule's opinion is related to the teaching profession, a teacher must have individual competence and high professional awareness, and this is shown by having a good personality, the ability to teach based on educational science, and recognition as an educator with a certificate as an educator. Ethical principles and having a professional organization show that teachers must have good social competence with the people around them.

A teacher who has quality performance can be said to be a teacher who is capable of carrying out the learning process both in the classroom and outside the classroom, besides that the teacher is able to carry out various other activities, such as school administration, learning, guidance and services to students, as well as being able carry out an assessment in the learning process. In addition, according to Syafri Mangkuprawira and Aida Vitayala in Yamin and Maisah, they revealed several factors that influence performance, namely 1 ) individual performance factors, 2) group performance factors, 3) organizational performance factors (Hasibuan, 2019).

As a support measure for the creation of competent and professional teachers and in order to achieve the vision of national education through a quality learning process, it is necessary to develop a continuous and regular teacher performance assessment. Teacher performance appraisal is one of the tools to pinpoint teacher activities in the classroom, and help them improve their knowledge, skills, and professionalism (Ashari and Widiyaningsih, 2016).

Pondok pesantren is an educational institution led by a kyai. The development of Islamic boarding schools or not depends entirely on the policies of the kya. This means that the school organization or educational institution if it is declared successful and failed, the main determining factor is its leadership. The leader in a boarding school educational institution is led by a kyai, who is the founder and owner of the pesantren. Where a kyai has the absolute authority to make 
or take decisions and policies on the components contained in Islamic boarding schools to improve teacher performance (Wati, 2018).

The term policy (policy) is often translated into politics, rules, programs, decisions, laws, regulations, conventions, provisions, understandings, and other strategic plans. The concept of policy can also be interpreted as written rules or provisions of formal decisions of an institution or organization, it is binding in nature, regulates people's behavior in order to achieve goals, creates new values in the institution or organization.

Education policies, especially policies regarding the development and improvement of teacher performance, must at least meet the challenges and demands of global and contemporary developments as expressed by Fattah \& Latifah (2012) that education policy analysis describes how the State plans and aims at education priorities, then the results of this analysis must be explained by the existence of global policy factors (Disas, 2018).

Policy as a guideline consists of two noble values, namely: First, policies must be intelligent (intelligent) which can be simply understood as a way to solve problems according to the problem. So a policy must be drawn up after examining the data and structured in a scientific way. Second, policies must be "wise", that is, to solve problems without creating (new) problems. In addition, public policies must provide hope to all parties that policies will lead to changes that are better than now (Lasambouw, 2012).

Thus the existence of a kyai at the Islamic boarding school based on his role and function can be seen as a multi-functional leader, in addition to his role as the leader of the Islamic boarding school, the kyai is also tasked with compiling curriculum, creating rules, designing an evaluation system as well as implementing a teaching and learning system related to the knowledge he is also in. as a coach of community educators, as well as community leaders (Mahrudin, 2018). Because a leader can affect the performance of his subordinates or employees he leads. Performance really determines the results of achieving goals. According to Armstrong and Baron in Wibowo, performance is "the result of work that has a strong relationship with the organization's strategic objectives, customer satisfaction, and contributes to the economy" (Indra, 2017).

Based on the above discussion, it can be seen that the kyai's policy as the leader of the Islamic boarding school in improving teacher performance has a very important role so that the learning process can run according to the stated goals. But in running a boarding school, kyai does not run alone, but there needs to be people who can help and support the implementation of learning activities at the boarding school. Therefore, the teacher is one of the factors that most supports the kyai in the learning process. The purpose of this study is to describe the implementation of kyai policies in improving teacher performance at Darul Muttaqien Parung Islamic Boarding School, Bogor.

\section{B. METHOD}

The method used in this research is descriptive method. As stated by Subana (2011) that the descriptive method is the interpretation of data with regard to facts, circumstances, variables, and phenomena that occur during the research and presents as it is. Meanwhile, Nawai (2007) argues that the descriptive method is a problem-solving procedure that is investigated by describing or 
describing the condition of the subject or object of research (a person, institution, society, etc.) at the present time based on visible facts, or as it should be ( Wulandari, Fadillah, nd).

\section{RESULTS AND DISCUSSION Policy Implementation}

Implementation is the provision of means to carry out something that has an impact or effect on something. Something that is done to have an impact or that result can be in the form of laws, government regulations, judicial decisions and policies made by government agencies in the life of the state. Nurdin and Usman argued that implementation boils down to activities, actions, actions, or the existence of a system mechanism. Implementation is not just an activity, but an activity that is planned and to achieve the objectives of the activity. The definition of implementation stated, it can be said that implementation is not just an activity, but an activity that is planned and carried out in earnest based on the reference of certain norms to achieve the objectives of the activity. Therefore implementation does not stand alone but is influenced by the next object (Lisa'diyah, 2018).

The meaning of policy in English is "policy" which is distinguished from the word wisdom which means wisdom or wisdom. Policies are general statements of behavior rather than organizations. According to "Policy is a guideline for decision making". Policy is something that is useful and is also a system simplification that can help and reduce problems and a series of actions to solve certain problems, therefore a policy is considered very important (Sumarto, 2017).

According to Anderson, policy is the direction of action set by an actor or a number of actors in overcoming a problem. Meanwhile, according to Tilaar and Nugroho, education policy is the whole process and results of the formulation of strategic educational steps which are elaborated from the vision and mission of education in order to achieve the achievement of educational goals in a society within a certain period of time (Rahman, 2015).

The implementation of education in Indonesia is known as formal education which is carried out in a structured and tiered manner. There are also non-formal education policies covering life skills, early childhood education, youth education and others. This is in accordance with the Law on National Education System Article 26 paragraph (1), that non-formal education is organized as non-formal education as a complement to formal education. In order to support the implementation of education, it is demanded the presence of educational policies both formal and non-formal for educators and education providers (Rahman, 2015).

Studying policies is an important thing because it is a necessity for educational scientists to understand the study of public policy (public policy), especially educational policy (educational policy). This interest is closely related to the expected role of educational scientists, not only will it be expected to formulate quality education policies if educational scientists are involved in the policy-making process, but more than that, educational scientists are expected to play a big role. in providing corrections to various errors (inaccuracy) in the formulation of various education policies that have been produced by the government so far. Thus educational policy studies will provide a strong basis for someone who wants to develop a profession as an educational policy analyst (Madjid, 2018). 
Policies often fail because they are without formulation (planning) that is good, correct and in accordance with community needs. Whether a plan is good or not is determined by what is the orientation of the policy, how the formulation process is carried out, and who is the subject and object of the policy. A good policy is influenced by many elements and many determining aspects, from the very beginning of a policy to be carried out to policy reform to obtain policies that are relevant and in accordance with the needs.

\section{Teacher Performance}

The definition of performance is put forward by Beery Staw (2003: 205) "performance is defined as the output of an individual or team that is decipted in their on description and for which they". Performance is defined as the individual or team output depicted in their job description and for that they are paid based on the value of their performance or the like. Jennifer M George, Gareth $\mathrm{R}$ Jones (2012: 159) that "performance is an evaluation of the result of the persons behavior: it involves determining how well or poorly a person has accomplished a task done a job". Performance is an evaluation of the results of a person's behavior. This includes determining how well or how poorly a person completes a task or job done. Another opinion regarding performance was put forward by Armstrong's (2009: 532) "performance is measured in several dimensions in term of the competencies required to achieve the target level of performance in a particular job or at a particular level in an organization". Performance is an evaluation of the results of a person's behavior, this involves determining how good and bad a person is in completing a task (Zahroh, 2017).

Performance According to Mangkunegara (2005) is the result of work in quality and quantity achieved by a person in carrying out his duties according to the responsibilities assigned to him. Performance can be divided into 4, namely: (1) individual performance describes the implementation of one's duties so as to provide results determined by the group or institution; (2) group performance describes the implementation of the main activities of a group so as to achieve the results determined by the institution; (3) the performance of the institution with respect to the implementation of all the main activities of an institution so as to achieve the mission or vision of the institution; and (4) program / policy performance with regard to the implementation of activities in the program or policy that have been implemented so as to achieve the program or policy objectives (Mardin, 2014).

Performance can be measured through certain measurements (standards), quality related to the quality of work produced, while quantity is the amount of work produced within a certain period of time, and timeliness is the suitability of planned time. In an effort to determine the performance of an individual, group, or organization, a performance assessment is carried out (Wibowo, 2009). Performance appraisal is a way of measuring the contributions of individual members of the organization to the organization; the goal is to reward previous performance and motivate performance improvements in the future. Performance appraisal is carried out to provide an assessment of work results or work performance obtained by organizations, teams, or individuals (Sulasmono et al., 2017).

To produce a quality learning process in schools, high teacher performance, professionalism and high dedication to the continuity of the educational process in schools is needed. To support the success of teacher performance in carrying out their duties and responsibilities as educators, Rusyan, et al. argued that the success of teacher performance can be supported by several 
factors, namely performance motivation factors, performance ethos, performance environment, task and responsibility factors and the existence of performance optimization (Hasibuan, 2019).

To see teacher performance, we must look at the performance indicators which consist of responsibility, commitment, discipline and motivation. Professional teachers must have 10 data competencies consisting of: mastery of learning materials, delivery of material, class management, use of media and learning resources, knowledge of educational foundations, management of PBM, lesson evaluation, utilization of guidance and counseling, implementation of classroom administration, and research. for the sake of teaching (Helmi, 2015).

According to Uno and Lamatenggo (2012) that teacher performance can be measured through the following five indicators: 1) Quality of work. This indicator relates to the quality of teacher work in mastering everything related to the preparation of planning learning programs and the application of research results in classroom learning. 2) Speed / working stability. This indicator is related to the accuracy of the teacher's work in adjusting the teaching material with the characteristics of students and the completion of the teaching program according to the academic calendar. 3) Initiative at work. This indicator is related to the teacher's initiative in using varied learning models according to the subject matter and the wise use of various school inventories. 4) Workability. This indicator relates to the ability of teachers to lead classroom conditions to remain conducive, management of teaching and learning activities, and assessment of student learning outcomes. 5) Communication. This indicator is related to the communication carried out by the teacher in the process of tutoring services with students who are less able to participate in learning and are open to receiving input for learning improvement (Rasto, 2016).

Thus teacher performance is the ability of a teacher in the implementation of learning and is responsible for the students under his guidance by increasing student learning achievement. Teacher performance can also be indicated by how much the required competencies are met, including pedagogical, personal, social and professional competencies. This performance will arise depending on the leadership of the kyainya. Can it generate motivation so that the teacher has a good performance, or vice versa, the teacher is getting further from the expected performance.

\section{Implementation of Kyai Policy in Improving Teacher Performance at Pondok Pesantren Darul Muttaqien Bogor}

Pesantren is known as the oldest Islamic education institution and system in Indonesia that grows and develops in society. In its operation, pesantren have core values that are not shared by other institutions. First, the whole life perspective (Kaffah) is as worship. Second, studying lifelong knowledge (Long life education) which is then practiced. Knowledge and worship are synonymous for him, which automatically will lead to a deep love for science as the main value. Third, sincerity of working for a common goal (Noor, 2019). The kyai is a central figure who has many roles, from being a leader, temporary boarding school, teacher and mentor to students, husbands and fathers in their own families who also live in the cottage. The position of the kyai as the leader of the pesantren is also required to uphold the noble values which become the reference in behavior and development of the pesantren. The noble teachings which became a kiai's belief in his life, when in leading at the pesantren did not contradict or deviate from the noble values that he believed from the beginning, both direct and indirect public trust in kyai or 
pesantren would fade. Because actually the noble values that are believed by kyai or Muslims are a force that is believed to be a gift from Allah SWT (Syarif, 2017).

Mas'ud included kyai in five typologies: (1) encyclopaedic and multidisciplinary clerics who concentrate themselves in the world of science; studying, teaching, and writing, produced many books, such as Nawawi al-Bantani. (2) Kyai who is an expert in one of the specialized fields of Islamic science. Because of their expertise in various scientific fields, their pesantren are sometimes named according to their specialization, for example the pesantren al-Qur'an. (3) Charismatic clerics who derive their charisma from religious knowledge, especially from their sufism, such as KH. Kholil Bangkalan Madura. (4) Kyai Dai traveling, whose attention and involvement is greater through lectures in conveying his knowledge as a form of interaction with the public along with the mission of sunnism or aswaja with effective rhetorical language. (5) Kyai movement, because of his role and extraordinary leadership skills, both in society and the organization he founded, as well as the depth of his religious knowledge, so that he became the most prominent leader (Kesuma, 2014).

One of the Islamic boarding schools in Indonesia, which is very concerned about improving teacher performance and has its own characteristics in educating its students is the Darul Muttaqien Parung Islamic Boarding School, Bogor. The success of the Darul Muttaqien Parung Islamic boarding school in Bogor to become one of the leading Islamic boarding schools in West Java did not just happen. He believes that the success of Darul Muttaqien Parung Bogor Islamic Boarding School, which was founded in 1988, cannot be separated from good management.

The implementation of the kyai's policy in improving the performance of teachers at Pondok Pesantren Darul Muttaqien Parung Bogor is based on Panca Jiwa which means Panca means five, soul means spirit, Pondok means boarding school institution, which substantively contains positive values that do not conflict with Islamic teachings. The five spirits of the pesantren, namely; Sincerity, Simplicity, Independence, Ukhuwwah Islamiyyah and Freedom (Sukarta, 2008).

\section{Sincerity}

Sincerity is a value that is the cornerstone of all teacher performance in Islamic boarding schools. Everything that is done must have a main vision to reach the pleasure of Allah. Ikhlas means giving up self-interest in working for creatures. Sincerity will make work very light with maximum results. Because offering all activities only for Allah is the highest vision of human action. At Darul Muttaqien Islamic Boarding School, sincerity is the first value that must be embedded in the teacher's heart. A sincere teacher is a teacher with a warrior mentality, while a teacher who is not sincere is a teacher with a coolie mentality. In accordance with the motto of the pondok "Be a warrior teacher and a teacher warrior. The warrior teacher is always oriented towards sincerity for the pleasure of Allah, not pragmatism oriented "(Sukarta, 2009).

In accordance with what was conveyed by Imam Al-Ghazali, that a sincere teacher is someone who works to perfect, clean, purify and guide his students to get closer to Allah SWT, solely to get His pleasure. He does not expect wages or rewards for teaching, as well as position, rank and position. He considers that teaching is an obligation for knowledgeable people as well as the value of worship to Allah, thus making their knowledge useful and acceptable to Allah SWT (Fathiyana, 2011). 


\section{Simplicity}

The value of simplicity can provide energy so that it is always within a professional framework at work. Simplicity is a reflection of modesty. Do not exaggerate both in performance and in dress and attitude. Because God himself condemns people who live in excess. Simplicity will lead to a balanced and proportionate performance. Simplicity will lead not to be lazy so that they do not work at all, and also not to work extreme enough to neglect the teacher's right to rest (Sukarta, 2008).

\section{Independence}

Independence is the value in working based on careful planning so that you can imagine targets clearly. Independent teachers are teachers who work on their own initiative not because of pressure and encouragement from others. Planning (planning) becomes a driver of independence which is directly proportional to the vision of the institution. Independence is a reflection of awareness of duties and obligations at work (Sukarta, 2009).

A teacher is a model for students, for this reason, the teacher should have exemplary skills such as strong life independence. The main basis for independent teachers is to have high selfconfidence and believe that they have extraordinary potential and are not owned by just anyone. So as a teacher, don't ever feel inferior or feel inadequate because in fact such feelings will only be a big barrier to leading students to the gates of success (Ulfah, 2013)

\section{Ukhuwah Islamiyah}

In Darul Muttaqien Parung Islamic Boarding School, Bogor, the value of ukhuwah Islamiyah is an important value in teacher performance. This is because in an organization it consists of people in clear lines of work. A team must have strong ties, where faith is a strong bond in carrying out all tasks in this institution. The sense of ukhuwah Islamiyah will have implications for the performance of a solid team. Because a solid team will have implications for maximum and professional performance (Sukarta, 2008).

\section{Freedom}

Freedom as the last value in Panca Jiwa Pondok is not freedom within a secular frame of mind. Because secularism means unlimited freedom. Freedom at Darul Muttaqien Islamic Boarding School is defined as freedom in creativity within the framework of Islamic law as an organizational basis for improving teacher performance (Sukarta, 2008).

Based on the explanation above, that the kyai's policy in improving teacher performance at Darul Muttaqien Islamic Boarding School has a very significant effect on the creation of a positive work culture. Because individual values will affect the individual's behavior. Then the positive organizational values will also affect the positive organizational work culture. However, these values are closely related to management. If management is not supported by a value that will be the driving force, then management will feel very arid. Islamic boarding schools as Islamic institutions require the values of Islamic teachings to remain the basis for the spirit of the performance of teachers. Where the principle of organization will give a more religious nuance if it is based on Panca Jiwa Pondok. 


\section{CONCLUSION}

Sourced from this discussion, the kyai policy as a leader in Islamic boarding schools in improving teacher performance has a very important role. But in running a boarding school, kyai does not run alone, but there need to be people who can help and support the implementation of learning activities, and teachers are one of the factors that most support the kyai's policy in an effective and efficient learning process. The kyai's policy in improving teacher performance at Pondok Pesantren Darul Muttaqien Parung Bogor is based on Panca Jiwa which substantively contains positive values that do not conflict with Islamic teachings. The five spirits of the pesantren, namely; Sincerity, Simplicity, Independence, Ukhuwwah Islamiyyah and Freedom.

\section{References}

A Ajan, A Mahrudin, dan M. M. (2018). Efektivitas Kepemimpinan Karismatik Kyai Dalam Meningkatkan Kinerja Guru. Jurnal Tadbir Muwahhid, 2(April), 33-45.

Abd. Madjid. (2018). Analsis Kebijakan Pendidikan. Samudera Biru.

Eka Prihatin Disas. (2018). Analisis Kebijakan Pendidikan Mengenai Pengembangan dan Peningkatan Profesi Guru. Jurnal Penelitian Pendidikan, 14, 158-166.

Fathiyana, L. (2011). Konsep Guru Yang Ikhlas Menurut Imam Al - Ghazali Dalam Kitab Ihya ' Ulumiddin. Institut Agama Islam Negeri Walisongo.

Hafid, M. (2017). Pengaruh Motivasi dan Kompetensi Guru Terhadap kinerja Guru Sekolah dan Madrasah di Lingkungan Pondok Pesantren Salafiyah Syafi'iyah Sukorejo. Jurnal JPII, 1(April), 293-314.

Harjali. (2016). Implementasi Evaluasi Kinerja Guru di SMA Al-Islam Joresan Mlarak Ponorogo. Nadwa :Jurnal Pendidikan Islam, 10(1), 79-107.

Hasibuan, A. A. (2019). Analisis Faktor-Faktor Peningkatan Kinerja Guru Dalam Upaya Pencapaian Kualitas Proses Pembelajaran di Sekolah. Al Amin: Jurnal Kajian IImu Dan Budaya Islam, 2(2), 149-159.

Helmi, A. (2015). Kinerja Guru Dalam Meningkatkan Prestasi Siswa Pada SMP Negeri 2 Babahrot Aceh Barat Daya. Jurnal Administrasi Pendidikan Pascasarjana Universitas Syiah Kuala, 3(1), 1-12.

Indra, A. S. Z. (2017). Pengaruh Kepemimpinan Kyai Terhadap kinerja Pengurus di Pondok Pesantren An-Nur Bantul Yogyakarta. Universitas Islam Negeri Sunan Kalijaga Yogyakarta.

Kesuma, G. C. (2014). Pesantren dan Kepemimpinan Kyai. TERAMPIL Jurnal Pendidikan Dan Pembelajaran Dasar, 1(1), 99-117.

Lasambouw, C. M. (2012). Analisis Kebijakan Tentang Otonomi Perguruan Tinggi dalam Bentuk Badan Hukum Pendidikan. Jurnal Sigma-Mu, 5(12), 37-54.

Lisa'diyah. (2018). Implementasi Metode Pembelajaran Pendidikan Agama Islam di Sekolah Menengah Atas Negeri (SMA) 11 Bandung. EDUKASI: Jurnal Penelitian Pendidikan Agama Dan Keagamaan, 16(1), 110-123.

Meria, A. (2016). Kompetensi Guru Kelas Madrasah Ibtidaiyah. Jurnal Tarbiyah Al-Awlad, VI(2), 610-624.

Moh. Yahya Ashari dan Widiyaningsih, P. M. (2016). Hubungan Antara Hasil Penilaian kinerja Guru Dengan Kompetensi Guru PAI Tingkat SLTP/MTS di Pondok Pesantren Darul Ulum Jombang. 2, 44-69.

Noor, M. (2019). Gaya Kepemimpinan Kyai. Jurnal Kependidikan, 7(1), 141-156.

Rahman, W. Y. (2015). Analisis Kebijakan Pendidikan Keluarga dalam Memantapkan Perilaku 
Moral Anak di Kabupaten Aceh Tengah. Jurnal Administrasi Pendidikan, 3(2), 104-114.

Rasto, K. dan. (2016). Kompetensi dan Kinerja Guru Berdasarkan Sertifikasi Profesi. JURNAL PENDIDIKAN MANAJEMEN PERKANTORAN, 1(1), 61-71.

Sarifudin, A. (2019). Peningkatan Kinerja Guru Dalam Implementasi Penilaian Sistem SKS Melalui Supervisi Akademik Pengawas Sekolah. Jurnal Edukasi Islami Jurnal Pendidikan Islam, 08(02), 417-434.

Sukarta, M. R. (2008). Catatan Untuk Para Pejuang (Cetakan !). DM Grafika Press. (2009). Menjaga Visi dan Tradisi Pesantren, Sebuah Upaya Pewarisan Nilai Kemuliaan Generasi Penerus Perjuangan yang Lebih Baik. DMGrafika.

Sulasmono, B. S., Wardani, K. W., Universitas, D., Satya, K., \& Salatiga, W. (2017). Peningkatan Kinerja Guru Melalui Pelatihan Beserta Faktor Penentunya. Jurnal Pendidikan IImu Sosial, 27(2), 38-47.

Sumarto. (2017). Perkembangan Politik dan Kebijakan Pendidikan Islam di Indonesia. Jurnal THAQÃFIYYÃT, 18(1), 107-127.

Syarif, Z. (2017). Manajemen Kepemimpinan Kyai dan Kontribusinya Terhadap Mutu Pendidikan Pesantren. FIKROTUNA: Jurnal Pendidikan Dan Manajemen Islam, 6(2), 521-531.

Trie Wulandari, Fadillah, S. L. (n.d.). Analisis Kinerja Guru Dalam Mengelola Pembelajaran Anak Usia Dini. Program Studi Pendidikan Guru Pendidikan Anak Usia Dini FKIP UNTAN, 1-15.

Ulfah, A. (2013). Membangun Kemandirian Guru Dalam Menghadapi Perubahan. Https://Uad.Ac.Id/Id/Membangun-Kemandirian-Guru-Dalam-Menghadapi-Perubahan/.

Wathani, M. N. (2020). Strategi Peningkatan Kompetensi Pedagogik dan Profesional Guru MI Melalui Supervisi Akademik Kepala Madrasah. Schemata Journal, 9(1), 53-72.

Wati, B. (2018). Kebijakan Pimpinan Pondok Pesantren Dalam Meningkatkan Mutu Madrasah Salafiyah Wustho (Msw) Hidayatul Qomariyah Kota Bengkulu. An-Nizom: Jurnal Penelitian Manajemen $\quad$ Pendidikan, 3(1), 8-16. http://ejournal.iainbengkulu.ac.id/index.php/annizom/article/view/971

Zahroh, M. N. (n.d.). Evaluasi Kinerja Guru Dalam Peningkatan Mutu Pendidikan di Yayasan Al Kenaniyah Jakarta Timur. Jurnal Manajemen Pendidikan, 139-149. 